\title{
ROLA KLIENTÓW W TWORZENIU EKO-INNOWACJI: DOŚWIADCZENIA POLSKICH FIRM
}

Z a r y s t r e ś c i: Celem niniejszego artykułu jest ukazanie roli klientów w tworzeniu ekoinnowacji przez polskie firmy-dostawców technologii środowiskowych. Artykuł prezentuje wyniki badań prowadzonych metodą wywiadów pogłębionych. W efekcie podjętych analiz można stwierdzić, że firmy cenią informacje pochodzące z popytowej strony rynku, zabiegają o nie, dbają o kontakt z klientami, starają się śledzić ich zachowanie i odpowiadać na zidentyfikowane potrzeby. Eko-innowacje tworzone przez firmy-dostawców technologii środowiskowych w Polsce to innowacje inspirowane przez użytkowników (ang. user-driven innovations). ${ }^{1}$

S ło w a k 1 u c z o w e: eko-innowacje, klienci, użytkownicy, technologie środowiskowe

K 1 a s y fik a c j a E L: L26

\section{WSTĘP}

W dobie dużej konkurencji rynkowej i stale zmieniających się potrzeb klientów, skuteczna reakcja na zmiany panujące w otoczeniu przedsiębiorstw stała się ważnym czynnikiem ich sukcesu [Homburg, Grozdanovic, Klarmann, 2007, s. 18]. Firmy aby istnieć i rozwijać się na tak konkurencyjnym rynku powinny stale kierować swoje działania w stronę odpowiedzi na szanse i zagrożenia stwarzane przez dynamiczne otoczenie, w tym szczególnie potrzeby klientów [White, Varadarajan, Dacin, 2003, s. 63]. Na przestrzeni lat można zaobserwować zmianę stosunku klientów do sytuacji panującej na rynku oraz oferowanych przez firmy produktów. Klienci stali się bardziej

* Adres do korespondencji: Magdalena Marczewska, Uniwersytet Warszawski, Wydział Zarządzania, Katedra Teorii Organizacji, ul. Szturmowa 1/3, 02-678 Warszawa, e-mail: marczewska.m.a@gmail.com.

1 Autorka uzyskała środki finansowe na przygotowanie rozprawy doktorskiej z Narodowego Centrum Nauki w ramach finansowania stypendium doktorskiego na podstawie decyzji numer DEC-2014/12/T/HS4/00311. 
świadomi i poinformowani oraz coraz bardziej chętni do wpływu na ostateczny kształt upragnionego produktu [Prahalad, Ramaswamy, 2004, s. 2]. Ich opinie, spostrzeżenia i pomysły coraz częściej pomagają przedsiębiorstwom w jeszcze lepszym dostosowaniu oferowanych produktów do wcześniej niezaspokojonych potrzeb klientów [Urban, Von Hippel, 1988, s. 569].

Celem niniejszego artykułu jest ukazanie wpływu klientów na powstawanie i rozwój eko-innowacyjnych produktów oferowanych przez przedsiębiorstwadostawców technologii środowiskowych w Polsce oraz analiza tego zjawiska z perspektywy zarządzania innowacjami i technologiami. Ponadto, artykuł określa znaczenie klientów jako źródło inspiracji dla tego typu innowacji. Badanie obejmuje zarówno decyzje firm dotyczące wprowadzania nowych rozwiązań, wycofania z produkcji istniejących, jak i dostosowywania ich do nowo zidentyfikowanych potrzeb klientów.

\section{KLIENCI W DZIAŁALNOŚCI INNOWACYJNEJ PRZEDSIĘBIORSTW}

Użytkownicy i klienci pełnią ważną rolę $w$ funkcjonowaniu firm. Odpowiednia identyfikacja ich potrzeb oraz nieustanne badanie motywacji zakupowych pozwala przedsiębiorstwom na dostosowanie oferty produktowej do panujących na rynku trendów, jednocześnie wyznacza dalszy kierunek rozwoju i przyczynia się do zwiększenia zainteresowania oferowanymi produktami (Johnson, Christensen, Kagermann, 2010, s. 51-61; Bower, Christensen, 2010, s. 20-34). Coraz częściej klientów i użytkowników postrzega się jako istotny bodziec wpływający na proces udoskonalania i rozwoju pomysłów na produkty czy usługi oraz istniejących rozwiązań (Carrillo-Hermosilla, Del Río, Könnölä, 2009, s. 17-19).

Jednym z pierwszych badaczy zajmujących się analizą rozwoju nowych rozwiązań w odpowiedzi na zapotrzebowanie zgłaszane przez klientów był Eric von Hippel (1988). Podkreślał on znaczenie tzw. wiodących użytkowników (ang. lead users) dla rozkwitu innowacyjności firm oraz oferowanych przez nie nowych rozwiązań. Twierdził, że wiodący użytkownicy są, w przeciwieństwie do innych klientów, bardziej skłonni do podejmowania współpracy z potencjalnymi dostawcami produktów, które będą zaspokajać ich potrzeby celem pomocy przy ich opracowaniu i wdrożeniu (Von Hippel, 1988, s. 107). Tego typu klientów, zdaniem autora, można scharakteryzować przy pomocy dwóch, następujących cech (Urban, Von Hippel, 1988, s. 569):

- antycypują potrzeby większych grup społecznych;

- zaspokojenie ich potrzeb przez nowe rozwiązanie przyniesie im duże korzyści.

Poprawna identyfikacja tzw. wiodących użytkowników jest możliwa m.in. 
przy użyciu odpowiedniej metodyki (Von Hippel, 1988, 2005) składającej się z identyfikacji trendów, na podstawie których użytkownicy stają się wiodącymi użytkownikami, rozpoznania wiodących użytkowników, rozwoju produktu przy wykorzystaniu informacji dostarczonych przez wiodących użytkowników, badania rynku w celu stwierdzenia, czy nowe rozwiązanie spełnia potrzeby typowych użytkowników (Rysunek 1).

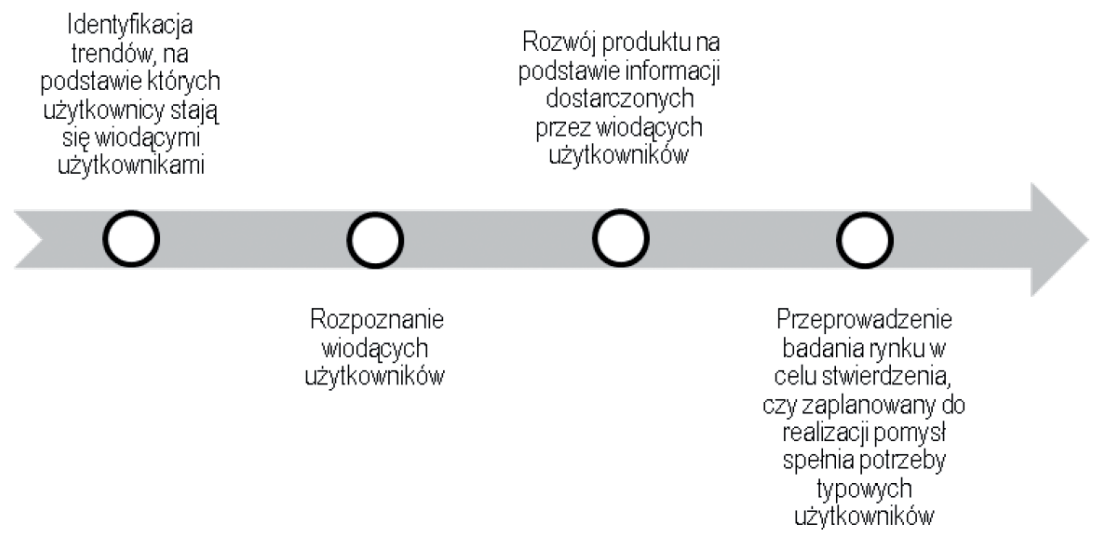

Rysunek 1. Metodyka identyfikacji tzw. wiodących użytkowników Źródło: Opracowanie własne na podstawie Von Hippel, 1988, 2005.

Badania empiryczne dowodzą, że różnorodne potrzeby klientów mogą być spełnione przez te same produkty, czy usługi oferowane przez przedsiębiorstwo. Dzieje się tak ponieważ niektórzy użytkownicy korzystają z produktów w inny sposób niż wynika to $\mathrm{z}$ ich pierwotnego przeznaczenia. Wiedza na ten temat jest dla firm niezwykle istotna, ponieważ może przyczynić się do wprowadzenia zmian $\mathrm{w}$ zakresie funkcjonalności oferowanych rozwiązań, pozytywnie wpłynąć na rozszerzenie portfolio produktowego i tym samym spowodować rozszerzenie grona klientów zainteresowanych produktem (Anthony, Eyring, Gibson, 2010, s. 125-126).

Istnieją różne sposoby umożliwiające firmom zdobycie informacji na temat klientów i ich oczekiwań, m.in. badania rynku, ankiety konsumenckie, sondaże, konkursy konsumenckie, systemy informatyczne, obserwacja, nieformalne kontakty z klientami. Mimo, że duża część przedsiębiorstw zbiera dane i informacje na temat osób i firm, które kupują oferowane przez nie produkty, bądź są zainteresowane kupnem, podejmowane wysiłki nie zawsze gwarantują uzyskanie satysfakcjonującej informacji zwrotnej, czyli oczekiwanej i zadowalającej wiedzy o klientach (Zook, 2010, s. 161-164). Badania empiryczne przeprowadzone przez Zooka (2010) dowodzą, że tylko 25\% firm, które nieustannie dążą o utrzymania dobrych kontaktów z klientami 
oraz monitorują ich zachowania, deklaruje, że rozumie w wystarczającym stopniu potrzeby użytkowników.

W literaturze przedmiotu strategia utrzymania długotrwałych relacji z klientami, ich budowy, zarządzania nimi oraz utrwalania lojalności klientów określana jest akronimem CRM (ang. customer relationship management). To szereg działań podejmowanych we wszystkich strukturach przedsiębiorstwa przy wykorzystaniu niezbędnej, specjalnie opracowanej infrastruktury, po to aby lepiej zrozumieć potrzeby, preferencje, motywacje i zachowania klientów (Dyché, 2002, s. 28; Tsiptsis, Chorianopoulos, 2009, s. 1-2; Peppers, Rogers, 2011, s. 6). Zarządzanie relacjami z klientem to, między innymi (Newell, 2002, s. 31):

- zidentyfikowanie kluczowych wartości, które dostarcza prowadzona działalność dla klientów;

- zrozumienie zidentyfikowanych wartości i przypisanie ich obsługiwanym oraz potencjalnych segmentom klientów;

- analiza wpływu dostarczenia zidentyfikowanych wartości klientom na zysk netto przedsiębiorstwa;

- dostarczenie wybranych wartości klientom z każdego segmentu w sposób najbardziej odpowiedni dla każdego z nich;

- badanie rezultatów podjętych działań celem zagwarantowania ich rentowności.

Badania Management Tools \& Trends przeprowadzone w 2013 roku potwierdzają, że przedsiębiorstwa coraz częściej postrzegają zarządzanie relacjami z klientem jako priorytetowe działanie (Rigby, Bilodeau, 2013), które obecnie jest coraz bardziej skoncentrowane wokół współtworzenia wartości z klientem. Z tych względów firmy w swojej działalności obok identyfikacji segmentów klientów powinny wkładać coraz więcej wysiłku w prowadzenie z nimi stałego dialogu (Prahalad, Ramaswamy, 2004, s. 132-134).

Przeprowadzony przegląd badań empirycznych dostarcza dowodów na to, że niektóre grupy klientów aktywnie uczestniczą w procesie tworzenia innowacji będąc ich współtwórcami, czy też współwynalazcami (Hienerth, Von Hippel, Baldwin, 2006, s. 1291-1313). Połączenie wysiłków przedsiębiorstw i klientów w procesie tworzenia nowego rozwiązania potwierdza, między innymi, przypadek oprogramowania CAD (Urban, Von Hippel, 1988, s. 569582), przypadek rowerów górskich (Luthje, Herstatt, Von Hippel, 2005, s. 951965) oraz przypadek innowacji w zakresie rafinacji ropy (Enos, 2013). Ponadto, użytkownicy o podobnych oczekiwaniach i potrzebach łączą się czasami w tzw. społeczności użytkowników innowacji (ang. user-innovation communities), gdzie współpracują, dzielą się posiadaną wiedzą i udzielają sobie wzajemnej pomocy w rozwijaniu nowych rozwiązań (np. społeczności open source) (Foray, 2006, s. 62-64). 
W literaturze przedmiotu nowe rozwiązania, na których powstanie ma wpływ zaangażowanie użytkownika nazywane są innowacjami popytowymi (ang. user-driven innovation - UDI). Powstające w ten sposób nowe rozwiązania mogą mieć znaczący wpływ na zakres i kierunek rozwoju produktów zarówno w odniesieniu do pojedynczej firmy, jak również całych branż (Von Hippel, 2005).

Na przestrzeni lat w praktyce gospodarczej można zauważyć różnorodne zmiany $\mathrm{w}$ zakresie relacji przedsiębiorstw $\mathrm{z}$ klientami oraz narzędzi wykorzystywanych przez firmy do identyfikacji i analizy oczekiwań, preferencji i zachowań obecnych i potencjalnych klientów. Dynamika tych zmian została szczegółowo przedstawiona w Tabeli 1. Zgodnie z badaniami Prahalada i Krishnana (2010) innowacyjne przedsiębiorstwa aby odnieść sukces powinny coraz bardziej koncentrować się na współtworzeniu wartości nie tylko $\mathrm{z}$ kluczowymi klientami, ale także z klientami z różnych segmentów. Zdaniem autorów, tego typu podejście gwarantuje lepszą identyfikację ewolucji zachowań obecnych i przyszłych klientów oraz może być przydatne w planowaniu przyszłej ścieżki rozwoju firmy (Prahalad, Krishnan, 2010, s. 72-86).

Tabela 1. Ewolucja i transformacja interakcji między firmą a konsumentem

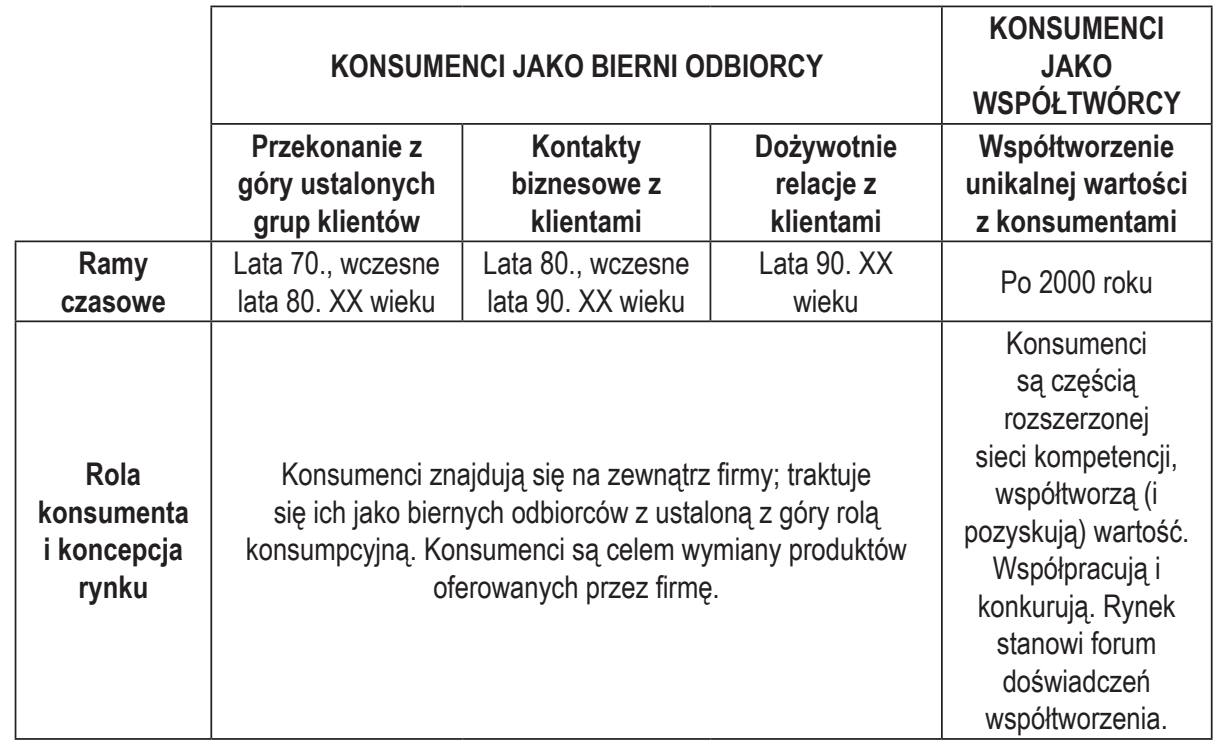




\begin{tabular}{|c|c|c|c|c|}
\hline $\begin{array}{l}\text { Konsumenci } \\
\text { w oczach } \\
\text { menedżerów }\end{array}$ & $\begin{array}{l}\text { Konsument } \\
\text { jest wielkością } \\
\text { statystyczna. } \\
\text { Odbiorcy są z góry } \\
\text { ustaleni przez } \\
\text { firmę. }\end{array}$ & $\begin{array}{l}\text { Konsument } \\
\text { jest jednostką } \\
\text { statystyczną } \\
\text { uczestnicząca } \\
\text { w transakcji; } \\
\text { od zapisu w } \\
\text { bazie danych } \\
\text { do jednostki, } \\
\text { z którą można } \\
\text { się kontaktować } \\
\text { indywidualnie. }\end{array}$ & $\begin{array}{l}\text { Konsument } \\
\text { jest osoba, } \\
\text { w zwiazku z } \\
\text { tym należy } \\
\text { kultywować } \\
\text { zaufanie i } \\
\text { wzajemne } \\
\text { relacje. }\end{array}$ & $\begin{array}{l}\text { Konsument jest } \\
\text { nie tylko osobą, } \\
\text { której indywidualną } \\
\text { tożsamość należy } \\
\text { szanować, lecz } \\
\text { także jest osadzony } \\
\text { we wspólnotach } \\
\text { tematycznych i } \\
\text { jest także częścią } \\
\text { pojawiającej się } \\
\text { tkanki społecznej } \\
\text { oraz kulturalnej. }\end{array}$ \\
\hline $\begin{array}{l}\text { Interakcje } \\
\text { przedsię- } \\
\text { biorstwa z } \\
\text { konsumen- } \\
\text { tami oraz } \\
\text { opracowanie } \\
\text { wyrobów } \\
\text { i usług }\end{array}$ & $\begin{array}{c}\text { Tradycyjne } \\
\text { badania rynku i } \\
\text { zapytania. Tworzy } \\
\text { się ustalanie } \\
\text { z góry wyroby } \\
\text { i usługi bez } \\
\text { wielu informacji } \\
\text { zwrotnych. }\end{array}$ & $\begin{array}{l}\text { Przechodzenie } \\
\text { od sprzedaży } \\
\text { do pomagania } \\
\text { konsumentom } \\
\text { przez stanowiska } \\
\text { pomocy, } \\
\text { telefoniczne } \\
\text { centra obsługi } \\
\text { i programy } \\
\text { obsługi klientów. } \\
\text { Rozpoznawanie } \\
\text { problemów } \\
\text { dzięki klientom, } \\
\text { następnie } \\
\text { przeprojektowanie } \\
\text { wyrobów i usług } \\
\text { na podstawie } \\
\text { informacji } \\
\text { zwrotnych. } \\
\text { Rozszerzona i } \\
\text { wiązana sprzedaż } \\
\text { konfigurowanych } \\
\text { z góry wyrobów i } \\
\text { usług. }\end{array}$ & $\begin{array}{l}\text { Zaopatrywanie } \\
\text { konsumentów } \\
\text { na podstawie } \\
\text { obserwacji } \\
\text { użytkowników } \\
\text { Rozpoznanie } \\
\text { rozwiązań dzięki } \\
\text { pierwszym } \\
\text { użytkownikom, } \\
\text { następnie } \\
\text { rekonfiguracja } \\
\text { produktów } \\
\text { na podstawie } \\
\text { głębokiej } \\
\text { znajomości } \\
\text { klientów. } \\
\text { Indywidualizacja } \\
\text { produkcji na } \\
\text { podstawie } \\
\text { ustalonych } \\
\text { z góry } \\
\text { właściwości. }\end{array}$ & $\begin{array}{l}\text { Konsumenci są } \\
\text { współtwórcami } \\
\text { wartości. } \\
\text { Dialog, dostęp, } \\
\text { rozpatrywanie } \\
\text { ryzyka i } \\
\text { przejrzystość } \\
\text { są elementami } \\
\text { konstrukcyjnymi } \\
\text { współtworzenia } \\
\text { wartości. Produkty } \\
\text { są częścią } \\
\text { środowiska } \\
\text { doświadczeń, w } \\
\text { którym poszczególni } \\
\text { konsumenci } \\
\text { współtworzą własne } \\
\text { doświadczenia. } \\
\text { Firmy i pierwsi } \\
\text { konsumenci } \\
\text { współkształtują } \\
\text { oczekiwania } \\
\text { i akceptację } \\
\text { rynkową środowisk } \\
\text { doświadczeń. }\end{array}$ \\
\hline
\end{tabular}




\begin{tabular}{|c|c|c|c|c|}
\hline $\begin{array}{c}\text { Cele i } \\
\text { przepływy } \\
\text { komunika- } \\
\text { cyjne }\end{array}$ & $\begin{array}{c}\text { Uzyskanie } \\
\text { dostępu i wybór z } \\
\text { góry ustalonych } \\
\text { grup klientów, } \\
\text { dostęp firmy do } \\
\text { wybranych grup; } \\
\text { komunikacja } \\
\text { jednokierunkowa. }\end{array}$ & $\begin{array}{c}\text { Marketing } \\
\text { prowadzony z } \\
\text { wykorzystaniem } \\
\text { baz danych; } \\
\text { dostęp firmy do } \\
\text { indywidualnych } \\
\text { osób; } \\
\text { komunikacja } \\
\text { dwukierunkowa. }\end{array}$ & $\begin{array}{c}\text { Marketing } \\
\text { relacyjny; } \\
\text { dwukierunkowy } \\
\text { dostęp i } \\
\text { komunikacja. }\end{array}$ & $\begin{array}{c}\text { Aktywny dialog } \\
\text { z konsumentami } \\
\text { (i współtwórcami } \\
\text { tematycznymi), aby } \\
\text { współkształtować } \\
\text { indywidualne } \\
\text { oczekiwania i } \\
\text { współtworzyć } \\
\text { osobiste } \\
\text { doświadczenia. } \\
\text { Wielokierunkowy } \\
\text { dostęp i } \\
\text { komunikacja } \\
\text { sieciowa. }\end{array}$ \\
\hline
\end{tabular}

Źródło: Prahalad, Ramaswamy, 2004, s. 214-215; Prahalad, Ramaswamy, 2005, s. 208-209.

\section{METODYKA BADAŃ}

Podjęte badania koncentrują się na wokół analizy źródeł powstawania ekoinnowacji w przedsiębiorstwach-dostawcach technologii środowiskowych i dotyczą w szczególności charakterystyki roli klientów w tym procesie. Dane do analizy zostały zebrane z wykorzystaniem wywiadów pogłębionych, częściowo standaryzowanych, częściowo ustrukturyzowanych na celowo dobranej próbie czterdziestu polskich przedsiębiorstw-dostawców technologii środowiskowych będących eko-innowacjami. Wybrane do analizy przedsiębiorstwa działają w ramach sześciu obszarów: odnawialne źródła energii (10 przedsiębiorstw), oszczędność energii (9 przedsiębiorstw), gospodarka odpadami (9 przedsiębiorstw), gospodarka wodno-ściekowa (7 przedsiębiorstw), ochrona bioróżnorodności ( 3 przedsiębiorstwa), ochrona powietrza ( 2 przedsiębiorstwa). Badane przedsiębiorstwa wyróżniają się wśród typowych uczestników rynku technologii środowiskowych w Polsce jako dostawcy własnych, ekologicznych i innowacyjnych produktów oraz ze względu na obecność na rynkach zagranicznych i zainteresowanie współpracą międzynarodową. Ponadto, są to firmy-laureaci trzech edycji projektu GreenEvo - Akcelerator Zielonych Technologii prowadzonego przez Ministerstwo Środowiska, którego celem jest, między innymi, wspieranie polskich, eko-innowacyjnych technologii. Firmy z badanej próby $\mathrm{w}$ ramach projektu podlegały ocenie niezależnych ekspertów, której celem była identyfikacja i ocena ekologicznego komponentu oraz poziomu wynalazczego dostarczanych przez nie rozwiązań.

Podstawą badania był scenariusz zawierający szczegółowe pytania dotyczące działalności przedsiębiorstw, w tym w szczególności procesu tworzenia przez nie eko-innowacji. Stanowił on swego rodzaju wytyczne porządkujące strukturę rozmowy (Gudkova, 2012, s. 121), natomiast końcowa kolejność zadawanych 
pytań oraz ostateczny sposób ich formułowania wynikały bezpośrednio z udzielanych przez rozmówców odpowiedzi. Wywiady przeprowadzono z właścicielami, członkami zarządu, menedżerami sprzedaży lub produktu. Zostały one nagrane, transkrybowane, anonimizowane i kodowane, a analiza zebranego i opracowanego w ten sposób materiału została dokonana zgodnie z założeniami teorii ugruntowanej (Glaser i Strauss, 2006). Zebrany materiał obejmował 6280 minut rozmów (104 godzin i 40 minut), a książka kodów powstała z 77 kodów.

\section{ROLA KLIENTÓW W TWORZENIU EKO-INNOWACJI}

Na podstawie krytycznej analizy literatury przedmiotu można twierdzić, że klienci mają wpływ na produkty i usługi oferowane przez przedsiębiorstwa. Ten wniosek potwierdzają również wyniki przeprowadzonych badań, które dodatkowo szeroko opisują specyfikę współpracy klientów z firmami-dostawcami technologii środowiskowych. 26 rozmówców z badanej próby potwierdza, że w wyniku podpowiedzi ze strony klienta powstał nowy produkt lub zostało wdrożone istotne udoskonalenie techniczne. W trzech $\mathrm{z}$ tych przypadków klient był bezpośrednio zaangażowany w proces opracowywania i testowania nowego rozwiązania, ponieważ zgłosił się do firmy z pomysłem na produkt, który nie był wcześniej dostępny na żadnym znanym mu rynku. Kolejne 10 firm twierdzi, że potrzeby i oczekiwania użytkowników wpływają na ostateczny kształt oferowanych przez nie rozwiązań, jednak nie są w stanie powiedzieć jak często wdrażane są pomysły pochodzące bezpośrednio od klientów. Wszystkie przedsiębiorstwa z badanej próby są natomiast zgodne co do faktu, że osobami, które mają wpływ na ostateczny kształt oferowanych przez nie rozwiązań są najczęściej użytkownicy i klienci, a rzadziej wykonawcy urządzeń, monterzy, czy dostawcy podzespołów. Ponadto, potwierdzają one, że informacje pochodzące od użytkowników i klientów obecnie znacznie częściej wykorzystywane są w procesie udoskonalania oferowanych przez nie produktów niż opracowywania zupełnie nowych.

„[...] bardzo często dostajemy sygnaty od klientów. Oczywiście nie ze wszystkich korzystamy, natomiast często nam klienci podpowiadaja i to sa albo jakieś malutkie innowacje takie racjonalizacje, powiedzmy, albo nawet $z$ podsunięciem jakichś zupetnie nowych rozwiazań."

\section{[Firma 1]}

Komunikacja przedsiębiorstw z klientami odbywa się na różne sposoby, natomiast $\mathrm{w}$ ramach danego przedsiębiorstwa jest spójna niezależnie od tego czy dotyczy klienta krajowego czy zagranicznego. Zdecydowanie najczęściej ma miejsce $\mathrm{w}$ bezpośrednich rozmowach na temat ich oczekiwań i potrzeb, które prowadzone są $\mathrm{w}$ następstwie podjęcia współpracy nakierowanej na sprzedaż produktu. Duża część klientów sama zgłasza się do firm z prośbą o 
pomoc $\mathrm{w}$ rozwiązaniu rozmaitych problemów, które napotkają w czasie jego użytkowania, nie zawsze bezpośrednio związanych z zakupionym produktem. W takich przypadkach firmy najczęściej podejmują współpracę z klientem celem znalezienia jak najlepszego rozwiązania zaistniałej sytuacji. Bywa również tak, że potencjalni klienci zwracają się z prośbą do firmy o wykonanie wymarzonego przez nich produktu, natomiast te drugie podejmują próby sprostania ich oczekiwaniom i wymaganiom.

„Klienci sa bardzo mądrzy $i$ w wielu przypadkach mówia, czego by jeszcze chcieli. Więc my reagujemy i zostawiamy takie ulepszenie $w$ produkcie, jakimś z jego wariantów. Dla nas taki klient, polski czy inny, tylko wzbogaca produkt."

[Firma 20]

Niektóre przedsiębiorstwa korzystają z zapisów zawartych w umowach, aby zagwarantować sobie kontakt z klientem oraz zapewnić otrzymanie informacji zwrotnej dotyczącej działania sprzedanego produktu. W badanej próbie znalazły się również firmy, które dzięki ankietom nakierowanym na pozyskanie informacji o oczekiwaniach klientów dowiadują się jakie dodatkowe funkcje w oferowanym przez nie produkcie są przez użytkowników pożądane.

„Po to sq te ankiety, o których wcześniej mówitem. To sa informacje od klientów. My staramy się pytać klientów czego oni potrzebuja i wychodzić z produktem, który spetnia ich oczekiwania. Nie chcemy narzucać swoich rozwiązań, bo bardzo rzadko zdarza się taki drugi Steven Jobs który potrafi tak odczytać rynek."

[Firma 17]

Mimo, że przeważnie współpraca z klientami jest korzystna, niekiedy nie przynosi ona oczekiwanych efektów. Wypracowanie kompromisu z klientem, szczególnie w chwilach, gdy pojawiają się problemy dotyczące działania zakupionego rozwiązania, czy też różnice zdań dotyczące oczekiwanych funkcjonalności rozwiązań, okazuje się niekiedy długotrwałe i uciążliwe, a czasem nawet niemożliwe. $\mathrm{Z}$ tego typu pobudek $25 \%$ firm $\mathrm{z}$ badanej próby (10 przedsiębiorstw) nie jest zainteresowanych zabieganiem o informację zwrotną na temat działania sprzedanego produktu. Ponadto, zdaniem tej części rozmówców, dostosowanie oferty produktowej do specyficznych potrzeb klientów bywa niekiedy zbyt kosztowne i może okazać się niewystarczające, a co za tym idzie niezbyt opłacalne dla przedsiębiorstwa. Nie wyklucza to jednak faktu, że również dla tych firm informacje pochodzące od klientów są interesujące i stanowią źródło inspiracji podczas tworzenia nowych rozwiązań.

Podsumowując, klient odgrywa bardzo ważną rolę $\mathrm{w}$ działalności innowacyjnej przedsiębiorstw-dostawców technologii środowiskowych, a komunikacja $\mathrm{z}$ nim to komunikacja dwustronna. $\mathrm{Z}$ jednej strony firma zabiega o utrzymanie dobrych relacji z użytkownikami produktów, z drugiej, klienci chcąc zapewnić sobie odpowiednią obsługę posprzedażową pozostają $\mathrm{w}$ stałym 
kontakcie z producentami (Rysunek 2). Firmy z badanej próby traktują wszystkie informacje pochodzące od klientów z rozwagą, analizują zgłaszane przez nich problemy i starają się w miarę możliwości odpowiadać na zidentyfikowane potrzeby i oczekiwania. Nie różnicują klientów względem kraju pochodzenia, zakresu udzielonej obsługi, ani innych kryteriów. W przypadku firm-dostawców technologii środowiskowych $\mathrm{w}$ Polsce to właśnie kontakt $\mathrm{z}$ klientami oraz potencjalnymi użytkownikami jest źródłem wiedzy i inspiracji do tworzenia i udoskonalania eko-innowacyjnych produktów.

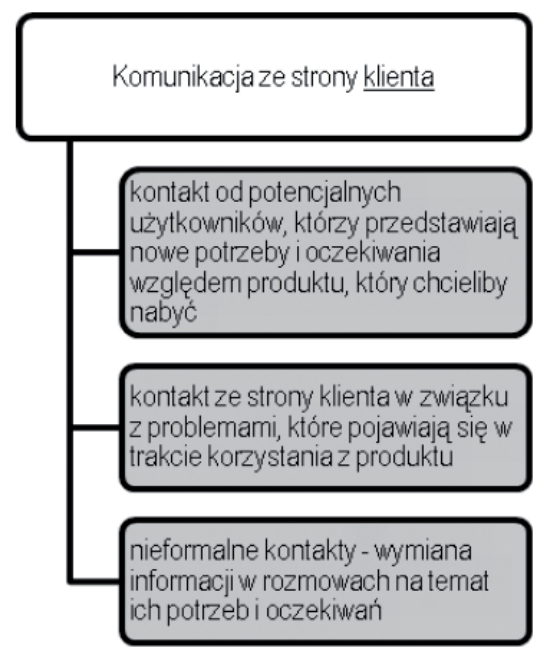

Komunikacja ze strony przedsiębiorstwa

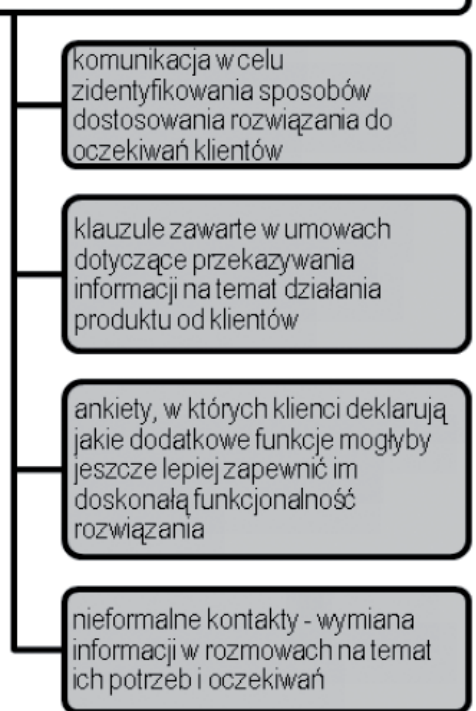

Rysunek 2. Sposoby pozyskania i utrzymania kontaktów z klientami przedsiębiorstwdostawców technologii środowiskowych

Źródło: Opracowanie własne na podstawie wywiadów.

\section{DYSKUSJA WYNIKÓW}

Zarówno krytyczna analiza literatury, jak i wyniki przeprowadzonych badań empirycznych dowodzą, że klienci mogą odgrywać istotną rolę w opracowywaniu innowacji, natomiast ich znaczenie dla działalności przedsiębiorstwa jest w dużej mierze zależne od strategii jego funkcjonowania. W czasach stale zwiększającej się konkurencji rynkowej i ciągle zmieniających się potrzeb klientów, odpowiednia i skuteczna reakcja na zmiany zachodzące w dynamicznym otoczeniu okazuje się ważnym elementem sukcesu firm (White, Varadarajan, Dacin, 2003, s. 63; 
Homburg, Grozdanovic i Klarmann, 2007, s. 18). Identyfikacja kluczowych dla firmy klientów, zrozumienie ich potrzeb, dopasowanie działalności do ich oczekiwań oraz pomiar ich zadowolenia i satysfakcji uwzględniający informacją zwrotną to jedna $\mathrm{z}$ możliwych strategii trafnego dopasowania oferowanych przez przedsiębiorstwo rozwiązań do potrzeb rynku (Newell, 2002, s. 31). Ponadto, firmy mogą wybrać i stosować jedno z czterech możliwych zdaniem Ansoffa i Stewarta (1967) podejść do wiedzy technologicznej i rynku, dzięki którym mogą zagwarantować sobie sukces jako pionier rynkowy, pretendent, udoskonalacz lub papuga (Ansoff, Stewart, 1967, s. 81-83; Klincewicz, 2010, s. 32-33).

Literatura przedmiotu z zakresu innowacji podkreśla ważną rolę klienta $\mathrm{w}$ procesie powstawania innowacji (Von Hippel, 1988; Janasz, Leśkiewicz, 1995; Drucker, 1992; Prahalad, Ramaswamy, 2004, s. 214-215), natomiast badania empiryczne dotyczące eko-innowacji traktują klientów jako dość istotny, natomiast nie kluczowy czynnik wpływający na rozwój tego typu nowych rozwiązań (Belin, Horbach, Oltra, 2009; Demirel, Kesidou, 2012; Muscio, Nardone, Stasi, 2013).

W przeciwieństwie do wyników niektórych badań empirycznych dotyczących eko-innowacji (Mazzanti, Zoboli, 2006; Demirel, Kesidou, 2012), przeprowadzone wywiady na próbie polskich przedsiębiorstw-dostawców technologii środowiskowych potwierdzają bardzo ważną rolę klientów w procesie tworzenia nowych rozwiązań. Rozmówcy wielokrotnie akcentowali, że podejmowana współpraca z klientami była udana i owocna dla dwóch stron. $\mathrm{Z}$ jednej strony przyczyniła się do zwiększenia funkcjonalności oferowanych przez firmy rozwiązań oraz stworzenia i rozwinięcia nowych produktów, z drugiej, umożliwiła klientom otrzymanie rozwiązania w pełni dostosowanego do ich potrzeb i oczekiwań. Mimo, że polskie przedsiębiorstwa-dostawcy technologii środowiskowych przykładają dużą wagę do relacji z klientami, należy zaznaczyć, że nie traktują ich jako współtwórców innowacyjnych rozwiązań w rozumieniu Prahalada i Ramaswamyego zgodnie z koncepcją ewolucji i transformacji interakcji między firmą a konsumentem (por. Tabela 1) (Prahalad, Ramaswamy, 2004, s. 214-215). Wynika to z faktu, że rzadko zdarza się, aby klienci byli bezpośrednio zaangażowani w proces rozwijania nowych produktów, natomiast częściej tylko udzielają podpowiedzi dotyczących nowych funkcjonalności, zgłaszają wymagania w zakresie działania technologii, informują o konieczności naprawy produktu czy o problemach związanych z działaniem produktów, które samodzielnie zidentyfikowali. Nie ulega wątpliwości, że przedsiębiorstwa $\mathrm{z}$ badanej próby bardzo chętnie korzystają $\mathrm{z}$ doświadczeń użytkowników technologii i starają się wdrażać w oferowanych produktach sugerowane przez nich ulepszenia i zmiany. Prowadzą także aktywny dialog z klientami, zarówno obecnymi jak i potencjalnymi. Równie 
często podejmują się konfiguracji urządzeń specjalnie do potrzeb określonego klienta. Niezależnie od występowania tych złożonych relacji między klientami a firmami-dostawcami technologii środowiskowych w Polsce, klienci postrzegani są przez nie najczęściej jako podmiot znajdujący się w ich otoczeniu, a nie jako element ich sieci kompetencji.

Powyżej przedstawione rozbieżności wniosków płynących $\mathrm{z}$ badań empirycznych na próbie polskich przedsiębiorstw-dostawców technologii środowiskowych oraz literatury przedmiotu mogą wynikać, między innymi, z kilku następujących przyczyn: po pierwsze, rynek technologii środowiskowych w Polsce jest rynkiem relatywnie młodym, po drugie, ekologiczna świadomość Polaków stosunkowo niska, po trzecie, liczba klientów zainteresowanych innowacyjnymi produktami w zakresie technologii środowiskowych niewielka w porównaniu do innych krajów, po czwarte, badane przedsiębiorstwa to jedne z najbardziej eko-innowacyjnych firm-dostawców technologii środowiskowych w kraju. Dodatkowo, istotny jest fakt, że proces tworzenia wielu rozwiązań oferowanych przez przedsiębiorstwa $\mathrm{z}$ badanej próby rozpoczął się jeszcze $\mathrm{w}$ czasie transformacji gospodarczej, kiedy możliwości klientów w zakresie dostępu do rynków zagranicznych były w pewnym stopniu ograniczone. Między innymi z powyższych względów, klienci, którzy byli zainteresowani ekologicznymi, innowacyjnymi produktami chętnie mówili producentom o sowich potrzebach i byli gotowi w różny sposób współpracować, aby otrzymać produkty dostosowane do ich potrzeb. Wśród tych klientów byli również tacy, którzy współtworzyli nowe rozwiązania wraz z przedsiębiorstwami. Takich przypadków było tylko kilka, a wszystkie miały miejsce pod koniec lat 80 . XX wieku.

Zaprezentowane powyżej wybrane wyniki przeprowadzonego badania jakościowego skłaniają do interesujących wniosków. Po pierwsze, za pomocą wywiadów pogłębionych zidentyfikowano i zbadano proces powstawania innowacji w polskich firmach-dostawcach technologii środowiskowych. Po drugie, że przedstawiono szczegółową charakterystykę roli klientów w tworzeniu eko-innowacji. Wyniki badań ujawniają również pewne szczególne cechy w zachowaniu badanych, polskich firm dotyczące roli klientów będących źródłem eko-innowacji.

\section{PODSUMOWANIE}

W niniejszym artykule wykorzystano różne podejścia teoretyczne żeby zbadać i określić rolę klientów w rozwoju eko-innowacyjnych produktów (Johnson, Christensen, Kagermann, 2010; Von Hippel, 1988; Anthony, Eyring, Gibson, 2010; Bower, Christensen, 2010). Opisu relacji pomiędzy przedsiębiorstwem a klientem dokonano przy użyciu klasyfikacji Prahalada i Ramaswamy'ego (2004). Na podstawie wyników badań można stwierdzić, że klienci są ważnym czynnikiem 
napędzającym innowacyjność firm-dostawców technologii środowiskowych w Polsce.

Podsumowując, wyżej wymienione argumenty dostarczają dowodów na to, że w działalności polskich przedsiębiorstw-dostawców technologii środowiskowych klienci pełnią ważną rolę, jednocześnie nie stanowią grupy współtwórców (ang. consumers as co-creators) nowych rozwiązań, z kilkoma wyjątkami, o których wspomniano. Zgodnie z klasyfikacją Prahalada i Ramaswamy'ego relację tych firm z klientami właściwie opisuje podkategoria „dożywotnie relacje z klientami” (ang. lifetime bonds with buyers) (Prahalad, Ramaswamy, 2004, s. 214-215). Ponieważ nowe rozwiązania tworzone przez przedsiębiorstwa $\mathrm{z}$ badanej próby często powstają $\mathrm{w}$ odpowiedzi na rozpoznane potrzeby i oczekiwania klientów, jak również bazują na ich pomysłach, można uznać, że eko-innowacje firm-dostawców technologii środowiskowych w Polsce to innowacje inspirowane przez użytkowników (ang. user-driven innovations UDI) (Von Hippel, 2005, TemaNord, 2006).

Z powyższej analizy wynika, że obserwacja rynku, w tym szczególnie jego strony popytowej, jest jednym $\mathrm{z}$ fundamentalnych źródeł eko-innowacji $\mathrm{w}$ przypadku polskich firm-dostawców technologii środowiskowych.

Równocześnie należy podkreślić, że opisane wyniki badań nie powinny być stosowane do całej populacji przedsiębiorstw. Pogłębione wywiady były przeprowadzone na celowo dobranej próbie polskich firm-dostawców własnych, innowacyjnych, zaawansowanych technologii przyjaznych dla środowiska, podczas gdy wśród innych przedsiębiorstw w ramach sektora technologii środowiskowych znajdują się również dystrybutorzy technologii oraz producenci mniej zaawansowanych rozwiązań.

\section{LITERATURA}

Ansoff I.H., Stewart J.M., (1967), Strategies for a technology-based business, „Harvard Business Review", nr. 45(6).

Anthony S.D., Eyring M., Gibson L., (2010), Mapping your innovation strategy, [w:] Harvard Business Review on business model innovation, Harvard Business Press, Boston.

Belin J., Horbach J., Oltra V., (2009), Determinants and specificities of eco-innovations - an econometric analysis for France and Germany based on the Community Innovation Survey, DIME.

Bower J. L., Christensen C. M., (2010), Disruptive technologies: catching the wave, [w:] Harvard Business Review on business model innovation, Harvard Business Press, Boston.

Carrillo-Hermosilla J., Del Río P., Könnölä T., (2009), Eco-innovation. When sustainability and competitiveness shake hands, Palgrave Macmillan, New York.

Demirel P., Kesidou E., (2012), On the drivers of eco-innovations: empirical evidence from the UK, „Research Policy”, nr. 41.

Drucker P.F., (1992), Innowacja i przedsiębiorczość. Praktyka i zasady, PWE, Warszawa.

Dyché J., (2002), CRM. Relacje z klientami, Helion, Gliwice. 
Enos J.L., (2013), Petroleum progress and profits: a history of process innovation, Literary Licensing, Whitefish.

Foray D., (2006), The economics of knowledge, The MIT Press, Cambridge, London.

Glaser B., Strauss A., (2006), The discovery of grounded theory. strategies for qualitative research, Aldine Transaction, New Brunswick, London.

Gudkova S., (2012), Wywiad w badaniach jakościowych, [w:] Jemielniak, D. (red.), Badania jakościowe. Metody i narzędzia, Wydawnictwo Naukowe PWN, Warszawa.

Hienerth C., Von Hippel E., Baldwin C.Y., (2006), How user innovations become commercial products: a theoretical investigation and case study, „Research Policy”, nr. 35.

Homburg Ch., Grozdanovic M., Klarmann M., (2007), Responsiveness to customers and competitors: the role of affective and cognitive organizational systems, „Journal of Marketing”, nr. 71(3).

Janasz W., Leśkiewicz I., (1995), Identyfikacja i realizacja procesów innowacyjnych w przedsiębiorstwie, Uniwersytet Szczeciński, Szczecin.

Johnson M.W., Christensen C.M., Kagermann H., (2010), Reinventing your business model, [w:] Harvard Business Review on business model innovation, Harvard Business Press, Boston.

Klincewicz K., (2010), Zarządzanie technologiami. Przypadek niebieskiego lasera, Wydawnictwo Naukowe Wydziału Zarządzania Uniwersytetu Warszawskiego, Warszawa.

Luthje C., Herstatt C., Von Hippel E., (2005), User-innovators and "local” information: the case of mountain biking, „Research Policy”, nr. 34.

Mazzanti M., Zoboli R., (2006), Examining the factors influencing environmental innovations, „FEEM Working Paper”, nr. 20.

Muscio A., Nardone G., Stasi A., (2013), Drivers of eco-innovation in the Italian wine industry, International European Forum on System Dynamics and Innovation in Food Networks, Innsbruck-Igls.

Newell F., (2002), Lojalność.com. Zarządzanie relacjami z klientem $w$ nowej erze marketingu internetowego, IFC Press, Kraków.

Peppers D., Rogers M., (2011), Managing customer relationships: a strategic framework, John Wiley \& Sons, New Jersey.

Prahalad C.K., Krishnan M.S., (2010), Nowa era innowacji, Wydawnictwo Naukowe PWN, Warszawa.

Prahalad C.K., Ramaswamy V., (2004), The future of competition. Co-creating unique value with customers, Harvard Business School Press, Boston.

Prahalad C.K., Ramaswamy V., (2005), Przyszłość konkurencji. Współtworzenie wyjątkowej wartości wraz z klientem, Polskie Wydawnictwo Ekonomiczne, Warszawa.

Rigby D., Bilodeau B., (2013), Management Tools \& Trends 2013, Bain \& Company, http://bain. com/Images/BAIN_BRIEF_Management_Tools_\%26_Trends_2013.pdf [30.05.2014].

TemaNord, (2006), Understanding user-driven innovation, Nordic Council of Ministers, Norden, Copenhagen.

Tsiptsis K., Chorianopoulos A., (2009), Data mining techniques in CRM: inside customer segmentation, John Wiley \& Sons, Chichester.

Urban G.I., Von Hippel E., (1988), Lead user analyses for the development of new industrial products, ,Management Science”, nr. 34(5).

Von Hippel E., (1988), The sources of innovation, Oxford University Press, New York, Oxford.

Von Hippel E., (2005), Democratizing innovation, The MIT Press, Cambridge.

White Ch.J., Varadarajan P.R., Dacin P.A., (2003), Market situation interpretation and response the role of cognitive style, organizational culture, and information use, „Journal of Marketing”, nr. 67.

Zook Ch., (2010), Finding your right amount of knowledge, [w:] Harvard Business Review on business model innovation, Harvard Business Press, Boston. 


\title{
THE ROLE OF CUSTOMERS IN THE DEVELOPMENT OF ECO-INNOVATIONS: EMPIRICAL EVIDENCE FROM POLAND
}

\begin{abstract}
The aim of this paper is to discuss the role of customers in the development of ecoinnovations created by Polish companies-suppliers of environmentally sound technologies. The research is based on in-depth, semi-structured interviews. The paper reveals that companies appreciate information coming from the demand side of the market, strive for it, care about having good relationship with customers, try to keep track of their buying behavior and to focus on responding to their identified needs. Eco-innovations created by the companies-suppliers of environmentally sound technologies in Poland can be seen as user-driven innovations.
\end{abstract}

Keywords: eco-innovations, customers, users, environmentally sound technologies 
